\title{
Do headstart programs work? Survival and body condition in headstarted Mona Island iguanas Cyclura cornuta stejnegeri
}

\author{
Néstor Pérez-Buitrago ${ }^{1,2,3, *}$, Miguel A. García ${ }^{2,3}{ }^{,}$Alberto Sabat $^{1}{ }$, Johanna Delgado ${ }^{4}$, \\ Alberto Álvarez ${ }^{3}$, Owen McMillan ${ }^{1,2}$, Stephan M. Funk ${ }^{1,2,5, *}$ \\ ${ }^{1}$ Center for Applied Tropical Ecology and Conservation, University of Puerto Rico - Río Piedras, San Juan, \\ Puerto Rico 00931, USA \\ ${ }^{2}$ Department of Biology, University of Puerto Rico - Río Piedras, San Juan, Puerto Rico 00931, USA \\ ${ }^{3}$ Department of Natural and Environmental Resources, Wildlife Division, San Juan, Puerto Rico 00906, USA \\ ${ }^{4}$ Texas A\&M University - Kingsville, Caesar Kleberg Wildlife Research Institute, Kingsville, Texas 78363, USA \\ ${ }^{5}$ Durrell Wildlife Conservation Trust, Les Augres Manor, Trinity, Jersey JE3 5BP, Channel Islands
}

\begin{abstract}
Headstarting refers to the raising of hatchlings in captivity and subsequently releasing them into the wild and it is a widely used tool to protect endangered species by increasing survivorship. Evaluating the success of headstart programs is necessary but challenging. We evaluated a headstart program for the endangered Mona Island iguana Cyclura cornuta stejnegeri by analyzing demographic and spatial data and by comparing growth rate, body condition, and external parasitic load of headstarted and wild iguanas. Hatchlings were released at about $3 \mathrm{yr}$ age. Minimum survival rate was $40.3 \%$, at 7.6 to 48.3 mo after release. Most migrated from the release site back to the rearing facilities about $633 \mathrm{~m}$ away. Density around the rearing facility increased from 7.5 to 11.5 iguanas $\mathrm{ha}^{-1}$ (25 of 75 captures were headstarted iguanas). Released headstarted iguanas exhibited growth rates similar to the maxima observed in captive and wild mid-sized iguanas. Growth rates decreased immediately prior to release, indicating that husbandry practices ought to be reviewed. There was no evidence for an effect of captivity on susceptibility to external parasites. Increased local density indicates that the program was successful. However, the longer-term success remains unknown, as most headstarted iguanas returned to the headstart facility without establishing territories typical for adult wild Mona iguanas.
\end{abstract}

KEY WORDS: Conservation management $\cdot$ Headstarting $\cdot$ Reintroduction $\cdot$ Rock iguana $\cdot$ Cyclura Mona Island · Caribbean· Puerto Rico

\section{INTRODUCTION}

Rock iguanas, genus Cyclura, are restricted to the Caribbean and are among the world's most endangered lizards (Alberts 2000). Primary reasons for their critical conservation status are restricted distribution to one or a small number of islands, habitat loss and fragmentation due to human development, introduced exotic animals, and in some cases, poaching (Alberts 2000). Introduced herbivores, especially goats, can significantly change and degrade habitats, thus reducing and fragmenting suitable iguana habitats. Introduced omnivores (e.g. pigs and rats) and carnivores (e.g. cats and mongooses) are particularly damaging to iguana populations because they can significantly increase egg and juvenile mortality. This reduces recruitment to adulthood and overall density, and produces a skewed population age structure (Iverson 1978, Alberts 2000, García et al. 2000).

Puerto Rico's endemic Mona Island iguana Cyclura cornuta stejnegeri is characterized by low density 
(2000 to 7500 iguanas in total at densities of 0.3 to 1.4 iguanas $\mathrm{ha}^{-1}$ ) compared to much higher densities reported for C. cornuta cornuta from Hispaniola (García et al. 2000, Pérez-Buitrago \& Sabat 2000, Wiewandt \& García 2000). For example, a survey of C. c. cornuta on Petite Gonave Island in Haiti indicated densities 26 times greater than those found for C. c. stejnegeri on Mona (García et al. 2000). Reported Cyclura densities range between 0.3 and 130 iguanas ha ${ }^{-1}$ with $75 \%$ of populations exceeding 10 iguanas ha ${ }^{-1}$ (Goodman 2004). All population estimates less than 1 iguana ha ${ }^{-1}$ stem from taxa predominately found in degraded habitats with introduced predators and ungulates, namely C. collei, C. lewisi, C. pinguis and C. C. stejnegeri (Goodman 2004). The age structure on Mona is strongly biased toward large, adult individuals, which is indicative of low and non-self-sustained levels of recruitment of juveniles into the breeding population (Wiewandt 1977). These 2 traits have led to the conclusion that the Mona population 'is abnormally small' (Wiewandt \& García 2000) and the listing as endangered by the International Union for Conservation of Nature (IUCN) (García et al. 2000). Two invasive species have had serious impacts on Mona Island iguanas; feral pigs depredate eggs and hatchlings, while feral cats prey on young iguanas (Wiewandt \& García 2000). Pigs are regularly hunted in order to reduce densities and their impact on iguanas, but there is no effective control program for cats. Eradicating both species is not regarded as feasible (Wiewandt \& García 2000). Meanwhile, as an additional management tool, a headstarting program was initiated in 1999 with the aim of increasing the survival probability through the neonatal period (Ferguson et al. 1982) and thus increasing the effective population size (García et al. 2007).

Removing detrimental invasive species is undoubtedly one of the most powerful conservation tools available to prevent extinctions of affected species, stop ecosystem change and restore ecosystems to their natural state. Although there have been significant successes in eradicating invasive species from island environments (e.g. cats, Nogales et al. 2004; goats and pigs, Kessler 2001), eradications are, in general, underutilized as a wildlife management tool as they are often technically difficult or very expensive (Donlan et al. 2003). Such programs can take a long time to become successful and are, therefore, not always a fast and efficient remedy (Cruz et al. 2005). Under these circumstances, headstart programs can constitute intermediate remedies to prevent further population declines and to promote population recovery. Headstart programs seek to increase the survival of juvenile animals by rearing hatchlings in captivity until they reach a size that makes them less vulnerable to predation once relocated into the wild (Ferguson et al. 1982).
In rock iguanas, headstarts have been utilized either as a management tool in highly endangered species with low juvenile recruitment (Jamaican iguana since 1991, Wilson et al. 2004; Anegada iguana since 1991, Bradley \& Gerber 2005) or to evaluate the performance and effectiveness of such programs (Cuban iguana since 1994, Alberts et al. 2004; Mona island iguana since 1999, García et al. 2007). However, information on the long-term success of iguana headstarts is limited. Survival estimates of headstarted iguanas range from 9 to $40 \%$, but sample sizes have been low and time periods relatively short (Cuban iguanas: 4 of 45 released iguanas were re-sighted at least once within 24 mo, Alberts et al. 2004; Jamaican iguanas: 8 of 20 released iguanas survived 24 mo or more, Wilson et al. 2004). In general, survival rates may be underestimated for both wild and headstarted iguanas, as juveniles are difficult to detect and marked animals likely emigrate from study sites (Wilson et al. 2004, PérezBuitrago \& Sabat 2007). None of the programs reported difficulties in captivity, such as high mortality or compromised animal health (Wilson et al. 2004). Success of headstarts might be increased by the enhancement of behavioral competency for survival and successful reproduction after release by careful design of captive conditions and release strategies (Alberts 2007). Empirical results on an experimental headstart program in Cuban iguanas indicate that captivity might have no significant effects on antipredator, thermoregulatory and social behaviors, or on food preferences and growth rates (Alberts et al. 2004).

A general lack of data on long-term survivorship, behavior of released animals, reproductive success, and impact on population recovery is notable even for turtles, for which headstarts were first utilized and have now been applied to many species (Heppell et al. 1996, Siegel \& Dodd 2000, Mitrus 2005). Headstarts have been criticized because they do not specifically address the causes of population decline and thus do not create self-sustaining populations (Frazer 1992, Heppell et al. 1996, Heppell 1998, Siegel \& Dodd 2000). Here, we assess the effectiveness of a headstart in the Mona Island iguana based on survival, recruitment, growth rates, body condition pre- and postrelease, migration distances from the release sites, and external parasite load (ticks Amblyomma sp.) of the first 2 cohorts of headstarted hatchlings for 3 to $4 \mathrm{yr}$ after release.

\section{MATERIALS AND METHODS}

Mona island $\left(53 \mathrm{~km}^{2}\right)$ is located in a deep-sea channel $\left(18^{\circ} 05^{\prime} \mathrm{N}, 67^{\circ} 54^{\prime} \mathrm{W}\right)$ between Hispaniola and Puerto Rico. There is no evidence of an historic con- 
nection of Mona, where the subspecies Cyclura cornuta stejnegeri occurs, with either Puerto Rico or Hispaniola (Wiewandt \& García 2000). Mona was designated as a Natural Reserve in 1973 and is administrated by the Puerto Rico Department of Natural and Environmental Resources (PR-DRNA). Mona's climate is subtropical with an annual mean precipitation of $810 \mathrm{~mm}$, a marked dry season from January to April, a mean annual temperature of about $25^{\circ} \mathrm{C}$, and humidity of 40 to $64 \%$ during the day and 89 to $100 \%$ during the night. The island is dominated by a karst geology and the vegetation is predominantly subtropical dry forest (Cintrón \& Rogers 1991). Distinct plant communities characterize 2 main landscape features, the coastal plain ( $5 \%$ of the total area) and the plateau (Cintrón \& Rogers 1991). Whereas the plateau has received very little human impact, a large portion of the coastal plain habitat has been highly disturbed by plantations of the exotic trees Casuarina equisetifolia and Swietenia mahogany, which have displaced the native coastal vegetation (Cintrón \& Rogers 1991).

Headstarting facility and study site. Mona's headstart program was initiated in October 1999 by building an enclosure facility next to the PR-DRNA staff facility at Playa Sardinera (Fig. 1). The Sardinera is characterized by the highest densities of wild iguanas recorded on Mona Island (7.5 iguanas ha ${ }^{-1}$, PérezBuitrago \& Sabat 2000). In 1999, 5 enclosures (each $3 \mathrm{~m}$ long, $3 \mathrm{~m}$ wide and $2.3 \mathrm{~m}$ high) were established and 5 additional enclosures were built in 2000. Fencing excluded rats from entering the enclosures. Similarly, adult land crabs were excluded from entering, but were also prevented from leaving if they entered the enclosures at small body size. Each unit retained sand as the naturally occurring substrate and was improved by planting native plants. Rocks, perches and PVC pipes (100 mm diameter, $1 \mathrm{~m}$ long) were provided for climbing, hiding and basking. Enclosures were maintained twice per month by thorough cleaning, removal of any food remains and land crabs, and by pruning plants. Iguanas were fed a mixture of moisturized commercial food (Zeigler ${ }^{\circledR}$ iguana mash) on alternating days using 3 food stations in each enclosure composed of pieces of bamboo cut lengthwise. In addition, wild fruits, flowers and leaves were provided whenever available.

Animals. As the facility lacked equipment for incubating eggs, 62 hatchlings were collected during the hatching seasons in October 1999 and 2000 (n = 48 and $\mathrm{n}=14$, respectively) by digging up nests in 3 areas on the coast, Wiewandt, Mujeres, and Carabinero $(\mathrm{n}=33$, 24 and 5, respectively) (Fig. 1). These sites were chosen because they are characterized by high abundance of iguana nests. We aimed at collecting all hatchlings from each nest, but know that some hatchlings escaped. Hatchlings came from 8 nests in 1999 and 6 nests in 2000. Maternity and relatedness between nests were unknown, but it is possible that hatchlings from different nests were related to some degree. In 1999, the 48 hatchlings were kept in 5 enclosures ( 10 per enclosure). In 2000, those hatchlings, along with the 14 collected that year, were redistributed in a

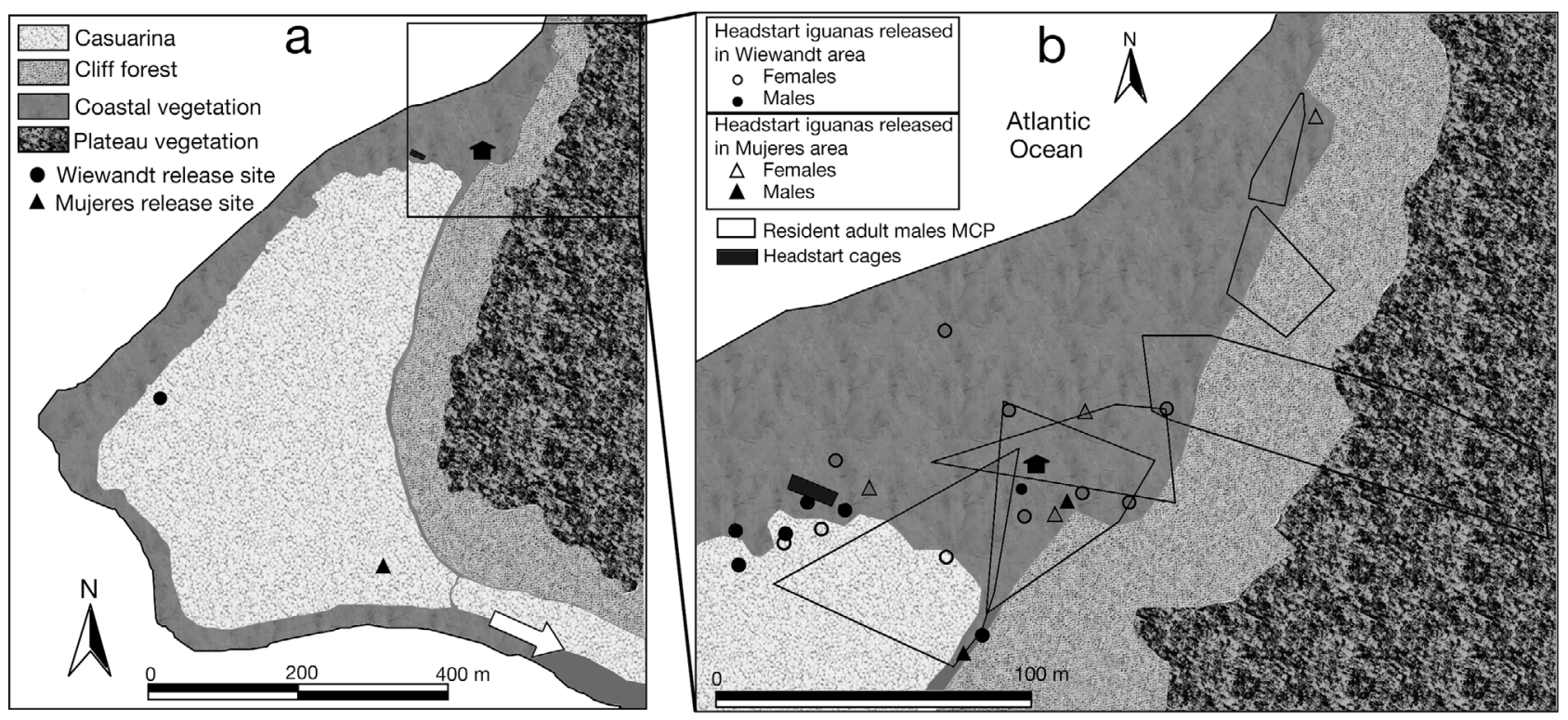

Fig. 1. (a) Overview of southwestern Mona Island with 2 of the 3 hatch-release sites: Wiewandt and Mujeres. The Carabinero hatch-release site is located outside the area shown (indicated by the arrow), $2.5 \mathrm{~km}$ southeast of (b) the Sardinera site. Polygons denote the Minimum Convex Polygon (MCP) home range boundaries of the adult males residing in the area. The house symbol (-) represents the staff kitchen where daily incidental feeding is provided to iguanas 
total of 10 enclosures ( 6 per enclosure). Although enclosure densities were thus different during the first year for the 1999 and the 2000 cohorts, respectively, no increase in variance of snout-vent lengths (SVL) (Fig. 2) and growth rates were detectable when comparing the data for the first year with subsequent years. Therefore density effects were not further analyzed.

Hatchlings were marked subcutaneously with Passive Integrated Transponders (PIT tags, AVID ${ }^{\circledR}$ ). We recorded SVL $( \pm 0.1 \mathrm{~mm})$, tail length $( \pm 1 \mathrm{~mm})$ and weight $( \pm 1 \mathrm{~g})$ of all individuals after collection and every 4 mo thereafter. During each check, we recorded the presence of ectoparasitic ticks (Amblyomma cruciferum and A. torrei) and counted ticks if present (Wiewandt 1977 , Durden \& Knapp 2005). For the Mona iguana, ticks are concentrated in axilliary and inguinal regions, but some highly infected individuals also had ticks on other body parts (Wiewandt 1977, authors' pers. obs.). The presence or absence of femoral pores, or cloacal probing, was used to determine sex in older juveniles (Schaefer 1934, Dellinger \& von Hegel 1990). As we observed no mortality, decrease in body condition or visible signs of disease, veterinary care was restricted to monitoring of overall body condition (body mass and ectoparasite load).

Release. Iguanas were released between April 2002 and October 2003, after reaching what we deemed sufficient body mass to escape predation by native predators (i.e. hawks) and feral cats. Iverson (1978) reported that cats predate the West Indian rock iguana Cyclura carinata up to a body mass of $510 \mathrm{~g}$ and $235 \mathrm{~mm}$ SVL. Lacking exact data for Mona iguanas, we released only individuals larger than $225 \mathrm{~mm}$ and heavier than $620 \mathrm{~g}$, regardless of age. Each individual was marked

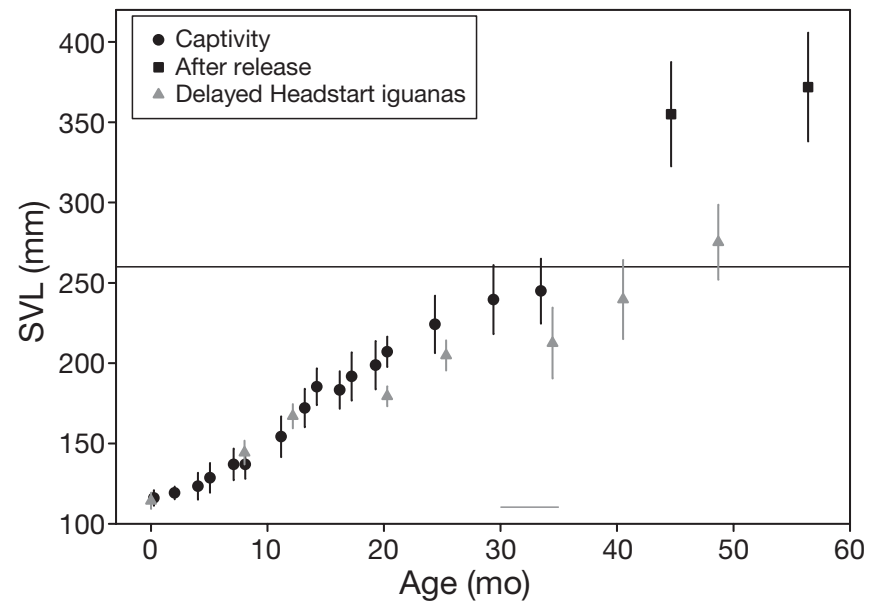

Fig. 2. Cyclura cornuta stejnegeri. Changes in snout-ventral length (SVL) during captivity $(\bullet)$ and after release (๘). Released iguanas were on average $33.1 \pm 3.5$ mo old (lower horizontal bar). ( $\triangle$ ) Iguanas held for 49 mo due to their small size. Horizontal line represents the average SVL at which iguanas were released. All iguanas were collected in 1999 and 2000 with a unique combination of colored beads attached to the dorsal crest prior to release (Rodda et al. 1988). Health screening consisted of a visual check for ticks (Amblyomma sp.) and for injuries such as missing toes and broken tails. Ticks and mites were rarely observed. Ticks were physically removed prior to release.

Iguanas were released at the nesting sites where they were collected as hatchlings (Fig. 1). These sites are located in a plantation of exotic trees, which might represent suboptimal habitat for juvenile or adult iguanas as we never observed iguanas there except during nesting season and at the edge of the plantation. Despite the suboptimal habitat, we adopted these release sites based on Wiewandt's (1977) suggestion of natal imprinting in females for the selection of nesting sites.

Post-release monitoring. Subsequent to the release, we extended monitoring of headstarted iguanas from the original capture sites to Sardinera area where iguanas are most numerous. The nearest boundary of the Sardinera capture area was approximately 1.3, 0.5 and $2.5 \mathrm{~km}$ distant from the 3 release sites, respectively (Fig. 1). An intensive capture program was conducted during the dry seasons (March), nesting seasons (July) and wet seasons (October) of 2003, 2004 and 2005. In 2006, captures were attempted only in the nesting and wet seasons.

All captured iguanas (wild and headstarted) were physically restrained. GPS locations, SVL, tail length and body mass were recorded. Unmarked individuals were PIT tagged and externally marked with colored beads if they were larger than $300 \mathrm{~mm}$ SVL or with colored wire if they were smaller. We quantified the external infestation with ticks, as with captive individuals (Wiewandt 1977, Durden \& Knapp 2005). After a handling interval of between 25 and 35 min, iguanas were released at the capture location.

SVL, tail length, body mass, body condition, and parasite load of headstarted individuals were monitored before and after release and compared with wild iguanas from the same study area. The body condition index (BCI) was calculated as the ratio of body mass ( $g$ ) and SVL (mm) following (Laurie 1989). This index has been used previously in marine iguanas (Romero \& Wikelski 2001) and in translocated St. Lucia whiptail lizard Cnemidophorus vanzoi (Dickinson \& Fa 2000). The relationship between SVL and body mass was compared between headstarted and wild iguanas by first fitting a regression line to wild iguanas only (weight $=a \times \mathrm{SVL}^{b}$ ), whereby the parameters $a$ and $b$ were estimated using the statistical package Statistica 5.5, and reporting the correlation coefficient $r$. The variance of weight varied largely over the range of observed SVL values and could not be normalized by a log-transformation (Sachs 1982). However, homogeneity of variances for the range of SVL values used for the 
comparison of headstarted and wild iguanas (300 to 450 mm; see Fig. 4) was not rejected (Cochran's C-test, $\mathrm{p}>0.05$; Sachs 1982). We then calculated the residuals for wild and headstarted iguanas using the regression derived from wild iguanas. A regression was fitted to the residuals for headstarted iguanas (residual weight $=c+d \times \mathrm{SVL}$ ) in order to evaluate if the variation in growth differed between wild and headstarted iguanas. We also compared the residuals of headstarted versus wild individuals using the Mann-Whitney $U$ test to determine if the residual variation in growth differed between wild and headstarted iguanas.

\section{RESULTS}

\section{Release and survival of headstarted iguanas}

The 62 released iguanas weighed between 0.62 and $1.32 \mathrm{~kg}(0.96 \pm 0.17 \mathrm{~kg}$, mean $\pm \mathrm{SD})$ and the SVL varied between 225 and $302 \mathrm{~mm}(258 \pm 19 \mathrm{~mm})$. Six individuals grew markedly slower than all other iguanas in captivity. These 'delayed' individuals (Fig. 2) reached the minimum release weight of $0.62 \mathrm{~kg}$ between 45.1 and $53.7 \mathrm{mo}(49.1 \pm 3.7 \mathrm{mo})$ whereas all other iguanas could be released after 22 to 36.3 mo in captivity $(33.1 \pm 3.5 \mathrm{mo})$.

Between March 2003 and October 2006, 75 different iguanas were captured in the Sardinera area. No iguanas were seen or captured outside the nesting and hatching periods inside of the Casuarina plantation, thus supporting evidence for zero or very low densities of mid-sized and adult iguanas in these plantations (Pérez-Buitrago \& Sabat 2000). From these 75 captured iguanas, 50 were wild and 25 were headstarted. The 25 recaptures represent $40.3 \%$ of the 62 released headstarted iguanas. Headstarted iguanas were recaptured 35 times ( 7 iguanas were recaptured twice and 1 was recaptured 4 times). Fifteen recaptures were from the 1999 cohort $(31.2 \%)$ and 10 from the 2000 cohort $(71.4 \%)$, but the proportions of recaptures were not statistically different from each other $\left(\chi^{2}=0.64, \mathrm{df}=1, \mathrm{p}>\right.$ 0.05). Ten males ( $40 \%$ ) and 15 females (60\%) were recaptured. Time between release and last recapture ranged from 7.6 to $61.3 \mathrm{mo}(29.8 \pm 17 \mathrm{mo})$. Corresponding ages at the time of the last recapture (including recaptures performed until July 2006) ranged from 32.3 to 91.3 months $(64.4 \pm 17.24 \mathrm{mo})$.

\section{Locations of recaptures}

The distance between release site and the location of the first recapture ranged between 441 and $1249 \mathrm{~m}$ $(633 \pm 147 \mathrm{~m})$. All recaptures were from the releases at the Wiewandt (16 of 33) and Mujeres sites (9 of 24), whereas none of the 5 individuals released at the more distant Carabinero site were recaptured. Some sightings or recaptures occurred within the Casuarina plantation, which contained the breeding sites where most of the headstarted iguanas were released, but were concentrated near the edges of the plantation. Although all habitats (Fig. 1) were systematically searched for iguanas, all recapture locations were aggregated around the headstart facilities. Whereas some female headstarted iguanas were seen and recaptured within the territories of resident males, male headstarted iguanas were exclusively observed and recaptured outside the territories of resident males, with the exception of the immediate surroundings of the staff kitchen, which showed a high concentration of headstarted iguanas of both sexes.

\section{Growth rates}

In captivity, there was a large variation in growth rates and a pronounced temporal pattern of growth rates within individuals. The large variation in growth rates is exemplified by the varying ages at which iguanas reached the target release size (see 'delayed' iguanas, above; Fig. 2). The pattern of growth was not uniform over time (Fig. 3). Growth rates varied from rapid growth during the first halfyear and the fourth half-year periods and slower growth rates during all other times, especially the 6 mo before release. However, growth rates increased strongly after release, as indicated by the fact that the 25 headstarted iguanas recaptured showed high and similar growth rates to those recorded during the peak

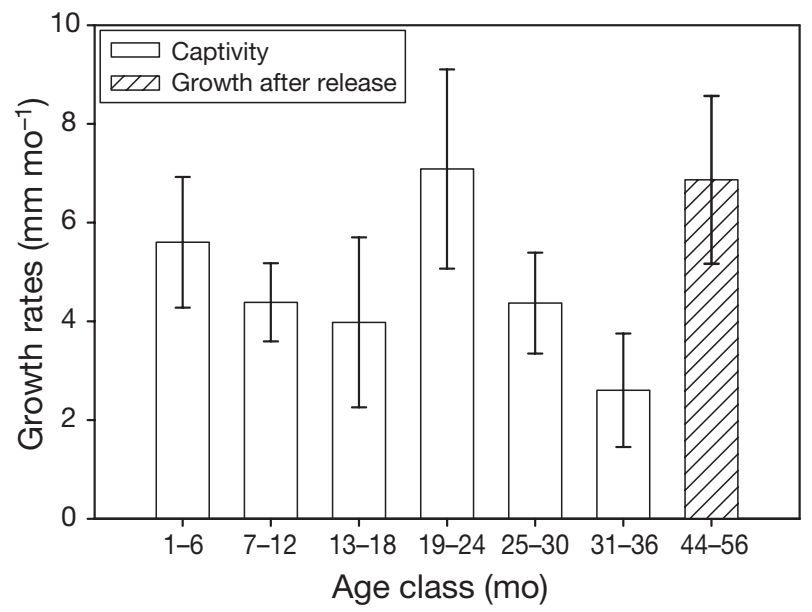

Fig. 3. Cyclura cornuta stejnegeri. Variation in growth rates of 25 headstarted iguanas in captivity in discrete periods of $\sim 6$ mo. Hatched bar represents growth rate $( \pm \mathrm{SD})$ at first capture after headstarted iguanas were released 
in captivity. In addition, there was no variation in growth rates between sexes $(t=1.69, \mathrm{df}=23, \mathrm{p}=0.10)$; thus both males and females were pooled for examination of overall growth rate for juveniles.

Growth rates of wild iguanas of comparable size to captive individuals were obtained from recaptures of 9 individuals during the dry, nesting and wet seasons (March, July and October, respectively). SVL ranged from 112 to $352 \mathrm{~mm}$ at the time of the first capture. Recaptures of these wild individuals occurred after 3.3 to $20.9 \mathrm{mo}(10.7 \pm 5.8 \mathrm{mo})$. Growth rates varied from 4.1 to $10.5 \mathrm{~mm} \mathrm{mo}^{-1}(6.3 \pm 2.2 \mathrm{~mm})$ and were thus in the upper range of the overall growth rates observed in captivity (Fig. 3).

SVL and body mass of wild and post-release headstarted iguanas ranged between 165 and $602 \mathrm{~mm}$ and from $0.15 \mathrm{~kg}$ to over $10 \mathrm{~kg}$, respectively, at first capture
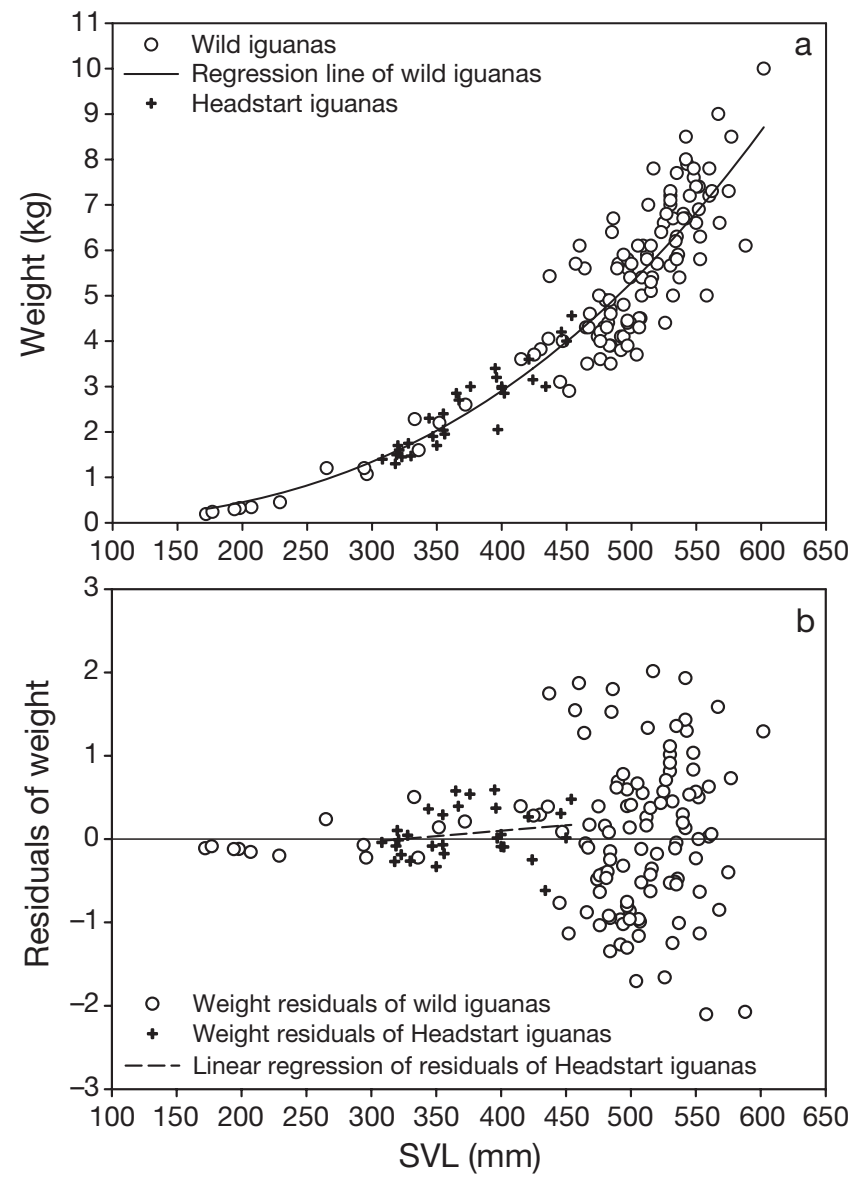

Fig. 4. Cyclura cornuta stejnegeri. (a) Snout-ventral length (SVL) and body mass of captured headstarted and wild iguanas. Regression (weight $=0.0000145 \times \mathrm{SVL}^{2.68}, \mathrm{r}^{2}=0.81$, continuous line) is based on wild iguanas only. (b) Residuals for wild and headstarted iguanas were calculated from the regression for wild iguanas. Regression (residual weight = $-0.078+0.00021 \mathrm{SVL}, \mathrm{r}^{2}=0.11$, dashed line) is based on the residuals of headstarted iguanas only. Data include only the first capture
(Fig. 4). Only $12 \%$ of the captured wild iguanas ( $\mathrm{n}=$ 50) were smaller than the target size of $235 \mathrm{~mm}$ SVL for releasing headstarted iguanas, and only $10 \%$ were mid-sized (between 235 and $400 \mathrm{~mm}$ ). Thus, small and mid-sized individuals were clearly underrepresented among captured wild iguanas. Captured headstarted iguanas ranged between 308 and $450 \mathrm{~mm}$ and between 1.3 and $4.2 \mathrm{~kg}$. These individuals represented the bulk of the mid-sized iguanas (SVL $<400 \mathrm{~mm}$ ) in the Sardinera population (Fig. 4). The regression for wild iguanas (Fig. 4a) explains $81 \%$ of the observed variance of wild iguana's weight $\left(\mathrm{r}^{2}=0.81\right)$. Data points for headstarted iguanas lie tightly around the regression curve and the regression of the residuals of headstarted iguanas explains only $11 \%$ of the variance $\left(\mathrm{r}^{2}=\right.$ 0.11; Fig. 4b). The residuals for headstarted and wild iguanas did not differ (Mann-Whitney $U$-test $=1649$, $z=0.50, \mathrm{p}=0.61$ ), indicating that captivity does not affect size-dependent body condition.

\section{Body condition, tick load, and reproduction}

There was no difference between the sexes in body condition index of headstarted iguanas at the time of the release $(t=0.30, \mathrm{df}=23, \mathrm{p}=0.77)$. Body condition was higher for headstarted iguanas prior to the release than at the time of the first capture (paired $t$-test $=5.1$, $\mathrm{n}=25, \mathrm{p}=0.00003$ ) (Fig. 5). However, body condition of headstarted iguanas at the time of the first recapture reached similar values to the body condition of wild mid-size and adult iguanas (ANOVA: $F_{2,69}=1.41, \mathrm{p}=$ 0.25) (Fig. 5).

Tick load during captivity and prior to release time was minimal (2 of 63 iguanas had 1 tick each prior release). Tick load of wild iguanas was positively cor-

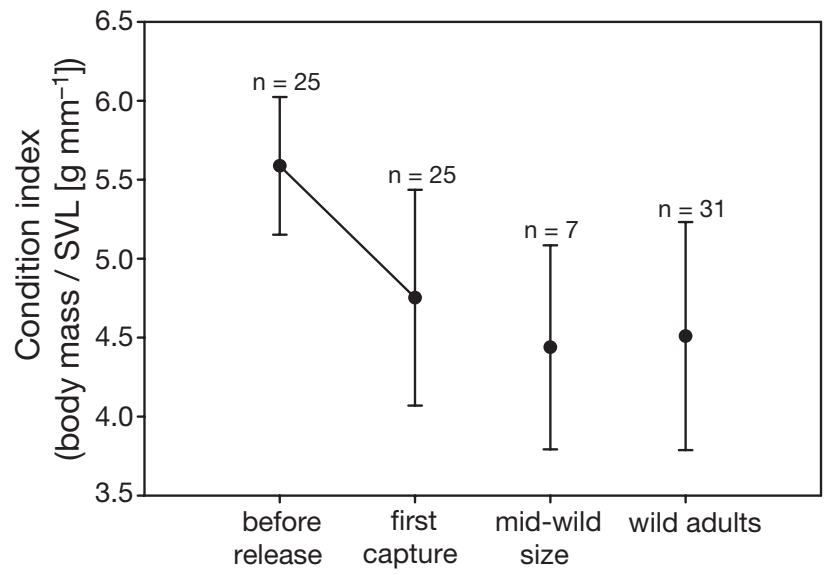

Fig. 5. Cyclura cornuta stejnegeri. Variation in body condition index in captivity and after release (connected bars) in comparison to wild mid-sized iguanas (SVL $<400 \mathrm{~mm}$ ) and wild large adults (SVL > $400 \mathrm{~mm}$ ). SD shown 
related with SVL $(\mathrm{r}=0.40, \mathrm{n}=64, \mathrm{p}<0.001)$ and this relationship was also valid when only wild mid-sized iguanas (235 to $420 \mathrm{~mm} \mathrm{SVL}$ ) were considered. After release, mid-sized headstarted iguanas acquired similar tick loads $(28.2 \pm 25.4$ ticks) to wild iguanas $(32.2 \pm$ 22 ticks $)$ of similar size $\left(t=0.40, \mathrm{n}_{\text {headstart }}=21, \mathrm{n}_{\text {wild }}=13\right.$, $\mathrm{p}=0.69$ ), but within that size range there was not a significant relationship between SVL and parasite load ( $\mathrm{r}=0.19, \mathrm{n}=23, \mathrm{p}>0.05)$. Circumstantial evidence indicates that ticks could be acquired quickly after release ( 1 released iguana acquired 7 ticks 4 d after release). There was a trend, albeit not significant, that females had more ticks than males $\left(\mathrm{n}_{\text {males }}=9, \mathrm{n}_{\text {females }}=\right.$ 13, $t=-2.04, \mathrm{p}=0.053$ ).

Opportunistic behavioral observations during the nesting seasons from 2003 to 2006 allowed us to detect 3 nesting headstarted iguanas (Female 1: recaptured in April 2004, age $=5 \mathrm{yr}, \mathrm{SVL}=376 \mathrm{~mm}$, weight $=3 \mathrm{~kg}$; Female 2: recaptured in April 2004, age $=4 \mathrm{yr}, \mathrm{SVL}=$ $344 \mathrm{~mm}$, weight $=2.30 \mathrm{~kg}$; Female 3: recaptured in July 2006, age $=7 \mathrm{yr}, \mathrm{SVL}=434 \mathrm{~mm}$, weight: $3.0 \mathrm{~kg}$ ). Female 1 nested near the headstart facility, $870 \mathrm{~m}$ away from the release site and reproduced successfully (8 eggs, of which 7 hatched successfully). Female 2 showed nesting behavior $665 \mathrm{~m}$ away from the release site but no eggs could be confirmed. Female 3 nested $1250 \mathrm{~m}$ from her release location and reproduced successfully (11 eggs, of which 10 hatched successfully).

\section{DISCUSSION}

Headstarted iguanas accounted for $71 \%$ of mid-size iguanas captured in the study area and represented $33 \%$ of the total Sardinera iguana captures. The capture program was intensive and by 2006, we no longer observed non-marked mid-sized and adult iguanas, indicating that all or almost all resident iguanas had been captured and marked in the Sardinera area. Thus, capture rates likely reflect abundance of wild and headstarted iguanas. Translating the numbers of captured iguanas at Sardinera (50 wild plus 25 headstarted) to density estimates, there was an increase from a minimum of 7.5 wild iguanas $\mathrm{ha}^{-1}$ to 11.3 wild and headstarted iguanas ha ${ }^{-1}$. This is the highest estimate for any Mona Island locality; elsewhere, estimates ranges from 0.3 to 1.4 iguanas ha ${ }^{-1}$ (PérezBuitrago \& Sabat 2000, Wiewandt \& García 2000). But this estimate is still low when compared to density estimates of other Cyclura populations, which in many cases reach values as high as 10 to 128 iguanas ha ${ }^{-1}$ (Goodman 2004). Headstarted individuals have supplemented captures of small and mid-sized wild iguanas and have thus increased minimum abundance in this age class. The apparent scarcity of small and midsized wild iguanas was reported across the whole island and in the Sardinera study site prior to release of headstarted individuals (Wiewandt 1977, PérezBuitrago \& Sabat 2000, 2007) and is thus unlikely the result of competitive interaction between headstarted and wild iguanas. Moreover, observations on the Hispaniolan subspecies (Cyclura cornuta cornuta) do not indicate that wild mid-size iguanas are particularly difficult to detect, as observations on Isla Beata reveal that approximately one-third of the population are small and mid-sized iguanas (García et al. 2000) compared to $20 \%$ at Sardinera. The apparent scarcity of small and mid-sized wild iguanas on Mona has been associated with low levels of recruitment (Wiewandt 1977, Pérez-Buitrago \& Sabat 2000) and was listed, together with overall low density, as the main rationale for the classification of the Mona iguana as endangered (García et al. 2000). The presence of headstarted iguanas and thus the increase in density and abundance suggest that the headstart program is accomplishing the primary goals of the recovery program, namely the increase of the population size.

However, the long-term effects and the success of the headstart program require further monitoring. Interestingly, most headstarted iguanas were captured in marginal and highly human-disturbed sites located adjacent to areas where wild resident iguanas have their home ranges year round. Radiotelemetry suggests that wild adult iguanas of both sexes are highly territorial and that some areas may already be at carrying capacity (Pérez-Buitrago et al. 2007). Therefore these areas offered limited opportunity for new individuals to immigrate and settle. Territoriality is likely to reduce recruitment opportunities due to failure of individuals to find optimal sites for establishing a territory (Pérez-Buitrago et al. 2007). Consequently, increased survival in young stages could be offset by reduced or failed reproductive success of headstarted iguanas.

\section{Survival}

Recapture rates are conservative estimates of minimum survival rates as some headstarted individuals could have escaped detection. Previous survival estimates for headstarted Cyclura iguanas 2 yr after release fluctuate from $9 \%$ for Cyclura nubila nubila (Alberts et al. 2004) to $40 \%$ for C. Collei (Wilson et al. 2004). Survival of C. pinguis was $83 \% 1 \mathrm{yr}$ post-release (Bradley \& Gerber 2005). The large variation in these estimates may result from actual differences in survival as much as the difficulties in monitoring individuals after release. However, all the estimates are 
within the range of juvenile survival rates reported for headstarted reptile species, including crocodilians and turtles (Alberts et al. 2004). The minimum survival rate of $40.3 \%$ of Mona headstarted iguanas is higher than the survival of $22 \%$ reported for wild Mona hatchlings during the first 5 mo of life (Pérez-Buitrago \& Sabat 2007). On the other hand, survival estimates between 0.5 and $6.5 \mathrm{yr}$ of age, the time span the Mona headstarted iguanas were observed, are much higher for other for wild iguanas (C. carinata: 50 to $74 \%$, Iverson 1979; C. cychlura inornata: $95.3 \%$, Iverson 2007). Minimum survival rates required to maintain the Mona population remain unknown. Thus, further monitoring is required to assess whether the headstart program is suitable to compensate for the assumed juvenile survivorship problem of wild Mona iguanas.

\section{Migration distances}

All headstarted iguana captures were in the Sardinera site near the headstart facilities (Fig. 1). Why those individuals returned to the site where they spent 2 or more years in captivity is unclear. It is likely, however, that the poor habitat (i.e. the Casuarina plantation) at the release sites, where no iguanas seem to live year-round (Pérez-Buitrago \& Sabat 2000), triggered migration. The assumption of natal imprinting in females for the selection of nesting sites (Wiewandt 1977), which led us to choose nesting sites as release sites, seems not supported by the choice of nesting sites by headstarted females. On the other hand, natal imprinting might require some time in the area of the nest. Whether headstarted iguanas exhibit natal imprinting and return to the place they were moved right after hatching needs to be experimentally tested. Applied management could address this issue by initial headstarting in areas that provide optimal habitat for juveniles, then moving them to the main headstarting facility.

Homing behavior is defined as the ability of animals to return to their usual home range when they are displaced from it (Jenssen 2002). Homing behavior has been reported for other lizard species (Freake 1998, Jenssen 2002), including one male Mona iguana that returned to its home site $1 \mathrm{wk}$ after being displaced $0.4 \mathrm{~km}$ (Wiewandt 1977). The capture locations suggest that headstarted iguanas exhibit homing behavior, as they returned and settled in areas near where they were raised. Radiotelemetry data from 9 headstarted iguanas showed very erratic movement patterns, with individuals covering an area averaging 12.9 ha during the first 5 mo after release (García et al. 2007). In contrast, mid-sized wild iguanas use much smaller areas (average $=1.4 \mathrm{ha}, \mathrm{n}=5$ ) than headstarted iguanas, but larger than adult individuals $(0.3 \mathrm{ha}, \mathrm{n}=$ 42 , both sexes pooled). Furthermore, the erratic movement patterns of headstarted iguanas also differ substantially from the much more directed dispersal displayed by hatchlings during the dispersal phase after hatching (Pérez-Buitrago \& Sabat 2007). The longterm effects of the differences between wild and headstarted iguanas we report here remain unknown and deserve additional research.

\section{Growth rates and body condition}

The only information on growth rates prior to this study was based on a single recapture $\left(4.4 \mathrm{~mm} \mathrm{mo}^{-1}\right.$ during the first year of life) (Wiewandt 1977). We observed a large variation in growth rates, though unrelated to sex. Averages ranged from $4.7 \pm 0.9 \mathrm{~mm}$ $\mathrm{mo}^{-1}$ in captivity, to $6.6 \pm 1.9 \mathrm{~mm} \mathrm{mo}^{-1}$ after release, and $6.0 \pm 2.3 \mathrm{~mm} \mathrm{mo}^{-1}$ for wild iguanas of similar size to headstarted iguanas. Overall, growth rates on Mona ranged from low values similar to other Cyclura species (C. carinata, $1.6 \mathrm{~mm} \mathrm{mo}^{-1}$, Iverson 1979; C. cychlura inornata, $1.4 \mathrm{~mm} \mathrm{mo}^{-1}$, Iverson et al. 2004; C. cychlura inornata, $2.5 \mathrm{~mm} \mathrm{mo}^{-1}$, Knapp 2001; C. cychlura figginsi, $0.7 \mathrm{~mm} \mathrm{mo}{ }^{-1}$, Coenen 1995; C. pinguis, $4.2 \mathrm{~mm} \mathrm{mo}^{-1}$, Gerber 2000) to high values similar to those observed in mainland Ctenosaura $\left(9.8 \mathrm{~mm} \mathrm{mo}^{-1}\right.$, Iverson \& Mamula 1989; $11 \mathrm{~mm} \mathrm{mo}^{-1}$, Van Devender 1982) and Iguana iguana (17.4 $\mathrm{mm} \mathrm{mo}^{-1}$, Harris 1982).

Of high relevance for captive management of iguanas is the pronounced decline in growth rates at the beginning of the third year in captivity (Fig. 3). Whereas the growth rate during the first 2 yr was comparable to that in wild iguanas, the subsequent decline suggests that density in captivity became less appropriate over time. With increasing age, conditions in captivity may produce stress due to crowding or aggression, which in turn induce decreased growth rate. This is also the likely reason that some individuals reached the release size much later than their enclosure mates (Fig. 3). That decreased growth rates were induced by captivity is clearly supported by the increased rate after release, which was comparable to that found in mid-size wild iguanas. Body condition decreased after the release, but this decrease is of no major concern, as body condition reached values similar to those of wild mid-size and adult iguanas between the first and subsequent recaptures (Fig. 5). The initial decrease of body mass is not surprising, considering the slower growth rate prior to release and that energy expenditure after release is certainly increased for resource and shelter acquisition and increased movements. Headstarted iguanas did not differ in their sizedependent body condition from wild iguanas of similar 
body size (Fig. 4). As wild iguanas had access to increased food availability due to artificial feeding, the condition index might have been higher than without food provisioning. In that case, a headstarted individuals' body condition would exceed the body condition of wild, non-supplemented iguanas.

A lower size or weight threshold for release is desirable in order to avoid the reduced growth rates observed during the third year in captivity. The smallest recaptured headstarted iguana was released at $0.7 \mathrm{~kg}$ of body mass, suggesting that this size could be considered as the minimum for future releases. However, lower release weights should be explored, such as for the Anegada headstart program, in which minimum release size was gradually reduced over time from $0.75 \mathrm{~kg}$ to $0.55 \mathrm{~kg}$ (Bradley \& Gerber 2005). On the other hand, the safer and faster alternative might be a reduction in densities in captivity to allow continued growth.

\section{Parasite load}

Tick load at the time of recapture represent ticks acquired after release as all ticks, if present, were removed prior to release. Ticks can be acquired fast in the wild, as the case of one iguana, which gained 7 ticks during $4 \mathrm{~d}$ between release and re-capture, indicates. In captivity, ticks were rarely acquired.

Ticks are the major parasites responsible for the transmission of the piroplasm Sauroplasma, but there is no evidence for any Cyclura species that Sauroplasma produces pathogenic effects (Alberts et al. 2004). However, ticks themselves can have negative effects on lizards by reducing sprint speed (Main \& Bull 2000) and hemoglobin content (Wikelski 1999). No evidence for different parasite load of headstarted and wild iguanas was observed, suggesting that headstarted iguanas are not more vulnerable to tick infestation than wild iguanas. Whether this indicates that captivity has no impact on immune competence in general will require more detailed data.

\section{Reproduction of headstarted iguanas}

Two of the 3 headstarted iguanas known to have shown nesting behavior were, at 4 and 5 yr age, younger than the estimated age for sexual maturity of females (6 to $7 \mathrm{yr}$; Wiewandt 1977). Whether this apparent early breeding was induced by captivity or whether maturity is size-based or whether early maturity in the wild was not detected remains unclear. These headstarted iguanas did not nest in the area where they hatched and where they were later released. At least in this case, the strategy to release iguanas at their own hatch site because of assumed natal imprinting did not result in the expected choice of nesting site. In contrast to the behavior of Galapagos iguanas (Christian \& Tracy 1982), radiotelemetry data during the nesting season reveal that young females make long and erratic movements visiting various nesting areas until choosing a nesting site (authors' unpubl. data). Therefore, we suggest that future release sites should be chosen in areas with optimal habitat and suitable nesting sites rather than relying on the tobe released iguanas' own hatching sites.

\section{Management implications}

The Mona Island headstart program was highly successful in increasing the density of mid-size iguanas in the study area. In this sense, the program is accomplishing its primary goals. However, whether this will lead to long-term population increase and recruitment of headstarted iguanas into the breeding pool remains to be seen. In particular, the dispersal from the release sites to the headstart facilities highlights some potential problems, at least for the Mona headstart program.

First, that area has the highest estimated density for any Mona locality, which is likely a consequence of the presence of humans in the area and daily provisioning of food resources to free-ranging iguanas. Headstarted individuals increased density even more. Anthropogenic-induced density increases can strongly impact mating system, demography, and population genetics (Lacy \& Martins 2003). Therefore, headstarted iguanas need to be released far away from the headstart facilities or headstart facilities need to be relocated. However, the choice of future release sites should not impinge on the current natural genetic structure. Dispersal of Mona iguana hatchlings can involve longdistance movements (the maximum recorded movement is half of the diameter of Mona; Pérez-Buitrago \& Sabat 2007) that may preclude any genetic differentiation among Mona localities, but this requires confirmation using molecular genetic tools (Rosas et al 2008). Second, the study highlights the gaps in our understanding of natal imprinting and homing in rock iguanas. Importantly, the origin of the homing of released animals back to the headstart facility remains unknown: imprinting over early life, nearest suitable habitat or food supplementation for free-ranging iguanas? Experiments with the choice of locations for releasing sites, and temporary and permanent headstart facilities would not only increase our knowledge but might allow us to direct juveniles to optimal places for settling. Third, homing might increase inbreeding if headstarted iguanas originate from the same nests. 
The relative endangerment of the species, its population size, and the difficulties in finding nests and/or collecting hatchlings should be considered, with a tradeoff established between the cost associated with raising related iguanas that could inbreed and the need to increase the number of reproductive animals in the population. Hatchlings can and should be collected from as many nests as possible to keep genetic variability high and reduce the risk of inbreeding. Finally, the reduction in growth rates during the third year in captivity suggests that either a reduction in density in the enclosures should be implemented or an earlier release date investigated.

Our study used available demographic and spatial data on wild rock iguanas to assess the success of a headstart program on Mona Island. Although the potential problems identified in this study may be peculiar to Mona, they have broader implications for other headstart initiatives in the Caribbean. The Mona iguana seems to benefit from headstarting, but the spatial behavior of released individuals, especially the returning to the vicinity of the headstart facility and the utilization of home ranges with artificial food provisioning, highlight the requirements for continued monitoring and adaptive management before concluding whether the headstart program has been successful and can accomplish full recovery.

Acknowledgements. US Fish and Wildlife Service-Section 6 Grants, the Division of Wildlife (Endangered Species Program) of the Natural and Environmental Resources Department of Puerto Rico, PR-DRNA, and the National Science Foundation through the CREST Center for Applied Tropical Ecology \& Conservation at the University of Puerto Rico (grant NSF HRD-0206200) provided financial support. We thank T. Reichard, W. Shellabarger and P. J. Tolson from the Toledo Zoological Garden for assistance. We are grateful for logistic support by PR-DRNA staff, especially I. García, C. Diez, A. Puente, G. Pons, M. Nieves, M. Pérez and J. Jimenez. A. Alberts, J. Iverson and 2 anonymous reviewers provided valuable comments on previous versions of this paper. This study was carried out with the appropriate institutional, state and federal permits and authorizations.

\section{LITERATURE CITED}

Alberts AC (ed) (2000) West Indian Iguanas: Status Survey and Conservation Action Plan. IUCN/SSC West Indian Iguana Specialist Group. IUCN, Gland, and Cambridge

Alberts AC (2007) Behavioral considerations of headstarting as a conservation strategy for endangered Caribbean rock iguanas. Appl Anim Behav Sci 102:380-391

Alberts AC, Lemm JL, Grant TD, Jackintell LA (2004) Testing the utility of headstarting conservation strategy for West Indian Iguanas. In: Alberts AC, Carter RL, Hayes WK, Martins EP (eds) Iguanas: biology and conservation. University of California Press, Berkeley, CA, p 210-219

Bradley KA, Gerber GP (2005) Conservation of the Anegada iguana (Cyclura pinguis). Iguana 12:79-85
Christian KA, Tracy CR (1982) Reproductive behavior of the Galapagos land iguana Conolophys pallidus on Isla Santa $\mathrm{Fe}$, Galapagos. In: Burghardt GM, Rand AS (eds) Iguanas of the world: their behavior, ecology and conservation. Noyes Publications, Park Ridge, NJ, p 366-379

Cintrón B, Rogers L (1991) Plant communities of Mona Island. Acta Científica 5:10-64

Coenen C (1995) Observations on the Bahamian Rock Iguana of the Exumas. Bahamas J Sci 2:8-14

Cruz F, Donlan CJ, Campbell K, Carrion V (2005) Conservation action in the Galàpagos: feral pig (Sus scrofa) eradication from Santiago Island. Biol Conserv 121:473-478

Dellinger T, von Hegel G (1990) Sex identification through cloacal probing in juvenile marine iguanas (Amblyhynchus cristatus). J Herpetol 24:424-426

$>$ Dickinson HC, Fa JE (2000) Abundance, demographics and body condition of a translocated population of St Lucia whiptail lizards (Cnemidophorus vanzoi). J Zool 251: 187-197

> Donlan CJ, Tershy BR, Campbell K, Cruz F (2003) Research for requiems: the need for more collaborative action in eradication of invasive species. Conserv Biol 17: $1850-1851$

Durden LA, Knapp CR (2005) Ticks parasitizing reptiles in the Bahamas. Med Vet Entomol 19:326-328

Ferguson GW, Brown KL, DeMarco VG (1982) Selective basis for the evolution of variable egg and hatchling size in some iguanid lizards. Herpetologica 38:178-188

> Frazer NB (1992) Sea turtle conservation and half-way technology. Conserv Biol 6:179-184

Freake MJ (1998) Variation in homeward orientation performance in the sleepy lizard (Tiliqua rugosa): effects of sex and reproductive period. Behav Ecol Sociobiol 43:339-344

García M, Pérez N, Wiewandt T (2000) Cyclura cornuta ssp. stejnegeri. In: 2006 IUCN Red List of Threatened Species. www.iucnredlist.org. Downloaded on 18 December 2007

García MA, Pérez-Buitrago N, Álvarez AO, Tolson PJ (2007) Survival, dispersal and reproduction of headstarted Mona Island iguanas, Cyclura cornuta stejnegeri. Appl Herpetol 4:357-363

Gerber G (2000) Conservation of the Anegada Iguanas Cyclura pinguis. Field Research report to the British Virgin Islands National Parks Trust, Fauna and Flora International, and the Zoological Society of San Diego, San Diego, CA

Goodman RM (2004) Spatial ecology and habitat use of the endangered iguana, Cyclura lewisi, in an unnatural setting. MSc thesis. University of Tennessee, Knoxville, TN

Harris DH (1982) The phenology, growth and survival of the green iguana Iguana iguana in northern Colombia. In: Burghardt GM, Rand AS (eds) Iguanas of the world: their behavior, ecology and conservation, Noyes Publications, Park Ridge, NJ, p 150-161

> Heppell SS (1998) Application of life-history and population model analysis to turtle conservation. Copeia 1998: 367-375

> Heppell SS, Crowder LB, Crouse DT (1996) Models to evaluate headstarting as a management tool for long-lived turtles. Ecol Appl 6:556-565

Iverson JB (1978) The impact of feral cats and dogs on populations of the West Indian Rock Iguana, Cyclura carinata. Biol Conserv 14:63-73

Iverson JB (1979) Behavior and ecology of the rock iguana, Cyclura carinata. Bull Florida State Mus Biol Sci 24: $175-358$

Iverson JB (2007) Juvenile survival in the Allen Cays Rock iguana (Cyclura cychlura inornata). Copeia 2007:740-744 
Iverson JB, Mamula MR (1989) Natural growth in the Bahamian iguana Cyclura cychlura. Copeia 1989:494-498

Iverson JB, Smith GR, Pieper L (2004) Factors affecting long term growth of the Allen Cays Rock Iguana, Cyclura cychlura inornata. In: Alberts A, Carter R, Hayes W, Martins E (eds) Iguanas: biology and conservation. University of California Press, Berkeley, CA, p 176-192

Jenssen TA (2002) Spatial awareness by the lizard Anolis cristatellus: Why should a non-ranging species demonstrate homing behavior. Herpetologica 58:364-371

Kessler CC (2001) Eradication on feral goats and pigs and consequences for other biota on Sarigan Island, Commonwealth of Northern Mariana Island. In: Turning the tide: the eradication of invasive species. IUCN SSC Invasive Species Specialist Group. IUCN, Gland, and Cambridge, p 132-140

Knapp CR (2001) Status of the translocated Cyclura iguana colony in the Bahamas. J Herpetol 35:239-248

Lacy KE, Martins EP (2003) The effect of anthropogenic habitat usage on the social behavior of a vulnerable species, Cyclura nubila. Anim Conserv 6:3-9

Laurie WA (1989) Effects of the 1982-1983 El Niño-Southern Oscillation event on marine iguana (Amblyrhynchus cristatus Bell, 1825) populations in the Galapagos Islands. In: Glynn P (ed) Global ecological consequences of the 1982-1983 El Niño-Southern Oscillation. Elsevier, New York, p 121-141

Main AR, Bull CM (2000) The impact of tick parasites on the behaviour of the lizard Tiliqua rugosa. Oecologia 122: 574-581

Mitrus S (2005) Headstarting in European pond turtles (Emys orbicularis): Does it work? Amphib-reptil 26:333-341

Nogales M, Martin A, Tershy BR, Donlan CJ and others (2004) A review of feral cat eradication on islands. Conserv Biol 18:310-319

Pérez-Buitrago N, Sabat A (2000) Population status of the Rock Ground Iguana (Cyclura cornuta stejnegeri) in Mona Island, Puerto Rico. Acta Científica 14:67-76

Pérez-Buitrago N, Sabat A (2007) Natal dispersal, home range and habitat use of hatchlings of the Mona Island iguana (Cyclura cornuta stejnegeri). Appl Herpetol 4:365-376

Pérez-Buitrago N, Sabat A, García MA, Funk SM, Álvarez AO, McMillan WO (2007) Spatial ecology of the Mona

Editorial responsibility: Mike Thompson,

Sydney, Australia
Island iguana Cyclura cornuta stejnegeri in an undisturbed environment. Appl Herpetol 4:347-355

Rodda GH, Bock BC, Burghardt GM, Rand AS (1988) Techniques for identifying individual lizards at a distance reveal influences of handling. Copeia 1988:905-913

Romero LM, Wikelski M (2001) Corticosterone levels predict survival probabilities of Galápagos marine iguanas during El Niño events. Proc Natl Acad Sci USA 98:7366-7370

Rosas KG, Perez-Buitrago N, Acevedo JP, Martinez N, Funk SM, McMillan WO (2008) Development and characterization of 11 microsatellite loci for the Mona Island iguana (Cyclura cornuta stejnegeri). Mol Ecol Resources 8: $825-827$

Sachs L (1982) Applied statistics. A handbook of techniques. Springer, New York

Schaefer WH (1934) Diagnosis of sex in snakes. Copeia 1934:181

Siegel RA, Dodd CK (2000) Manipulation of turtle populations for conservation: halfway technologies or viable options? In: Klemens MW (ed) Turtle conservation. Smithsonian Institution Press, Washington, DC, p 218-238

Van Devender RW (1982) Growth and ecology of spiny-tailed and green iguanas in Costa Rica, with comments on the evolution of herbivory and large body size. In: Burghardt GM, Rand AS (eds) Iguanas of the world: their behavior, ecology and conservation. Noyes Publications, Park Ridge, NJ, p 162-183

Wiewandt TA (1977) Ecology, behavior, and management of the Mona Island ground iguana, Cyclura stejnegeri. $\mathrm{PhD}$ thesis, Cornell University, Ithaca, NY

Wiewandt TA, García M (2000) Mona Island iguana. Taxonomic accounts. In: Alberts A (ed) West Indian iguanas. Status survey and conservation action plan. IUCN/SSC West Indian Iguana Specialist Group. IUCN, Gland, and Cambridge, p 27-31

Wikelski M (1999) Influences of parasites and thermoregulation on grouping tendencies in marine iguanas. Behav Ecol 10:22-29

Wilson BS, Alberts AC, Graham KS, Hudson RD and others (2004) Survival and reproduction of repatriated Jamaican iguanas. In: Alberts AC, Carter RL, Hayes WK, Martins EP (eds) Iguanas: biology and conservation. University of California Press, Berkeley, CA, p 220-231

Submitted: March 12, 2008; Accepted: August 7, 2008 Proofs received from author(s): October 8, 2008 